\title{
The Role of Courts in the Enforcement of Socio-Economic Rights under the 2013 Constitution of Zimbabwe
}

NDHLOVU, N.

\section{Abstract}

$T^{\mathrm{n}}$

he aim of this paper is to illustrate that courts play an important role in the domestic protection of socioeconomic rights. In order to ensure that socio-economic rights are effectively protected and enforced, this paper identifies and discusses the framework for protecting socio-economic rights under the 2013 Constitution. The paper discusses the role of the courts in the domestic framework for protecting socio-economic rights under the 2013 Constitution. Secondly, the study discusses the role of the courts in the protection of socioeconomic rights. The paper further identifies some of the major conceptual and practical challenges that are likely to arise in the adjudication of socioeconomic rights. In that regard, the study attempts to come up with solutions meant to overcome the conceptual and practical challenges that are faced in the enforcement of socio-economic rights. For example, instead of adopting a purely legal-centric approach in interpreting socio-economic rights, it is suggested that courts should adopt a multidisciplinary approach taking into account founding values, historical background, political background, international human rights law norms and comparative law.

Keywords: Law enforcement, Courts, Judiciary, Socio-economic rights, Constitution, Zimbabwe. 


\section{Introduction}

It is now widely accepted that without legal enforceability mechanisms, socio-economic rights amount to no more than pragmatic ideals (Wiles 2006:35-64). Thus, it is important to state that direct protection of socio-economic rights as justiciable entitlements offers the best opportunity to develop a jurisprudence which engages seriously with the content of these rights and the nature and scope of the obligations they impose. As such, socio-economic rights in the 2013 Constitution present the courts with an opportunity to enforce these rights. This inclusion of socio-economic rights in the Constitution is aimed at advancing the socio-economic needs of the Zimbabwean people, especially the vulnerable, impoverished and marginalised through the imposition of short and long term obligations on the state. The judicial enforcement of socioeconomic rights is a powerful indication that the Constitution's vision goes beyond merely guaranteeing abstract equality - rather courts must ensure that these rights become a reality. It is the vision of the Constitution to ensure democracy, transparency, accountability, good governance and the rule of law (Constitution 2013: section 3). Significantly, it is the vision of the Constitution to reaffirm the commitment to uphold and defend fundamental rights and freedoms which include socio-economic rights (Constitution 2013).

Moreover, an argument may be advanced that the constitutionalisation of socioeconomic rights is a commitment to transform Zimbabwe's society from one that is based on socio-economic deprivation to one that is based on equal and equitable distribution of resources (Liebenberg 2010:24). However, the Constitution does not provide a comprehensive blueprint for a transformed society nor stipulate the precise processes for achieving it. Instead, it provides a set of institutions, rights and values for guiding processes of social change and transformation. Consequently, individuals and groups who allege the infringement of their socio-economic rights should have the opportunity to seek relief or remedy in the courts and other non-judicial organs such as the Zimbabwe Human Rights Commission (UN CESCR 1991: para 3).

The principal aim of this article is to discuss and analyse judicial enforcement of socio-economic rights in Zimbabwe under the Constitution. Although it is beyond the scope of this article to engage in a comprehensive comparative analysis, reference will be made to the judicial enforcement of socio-economic rights under the 1996 South African Constitution. This is because the judiciary in that country has played a significant 
The Role of Courts in Enforcement of Socio-Economic Rights: 2013 Constitution of Zimbabwe 31

role. This article is divided into three sections; the first section explores and discusses the role of the judiciary in rights adjudication and how these rights should be interpreted in a transformative manner. This section further discusses international law, foreign law and the founding values in the Constitution as interpretative tools in respect of socioeconomic rights. The values espoused in the Constitution include, the respect of supremacy of the Constitution, fundamental rights and freedoms, recognition of inherent dignity and human worth and recognition of the equality of all human beings among others (Constitution 2013:section 3). The second section then explores the possible model for ascertaining state compliance with the protected rights. The third section discusses another conceptual and practical challenge in the socio-economic rights discourse, the remedial framework in adjudicating socio-economic rights.

\section{Role of judiciary under the Constitution}

Section 162 of the Constitution vests judiciary authority in the courts. The Constitution provides that it is supreme and all three main arms of government derive their authority from it (Constitution 2013). This means that all branches of government submit to the Constitution and every conduct must be consistent with the constitutional prescripts. However, under a constitutional supremacy, the judicial branch acquires a much more prominent role. This is because the judiciary has the task of policing the boundaries of action taken by the political branches to ensure that they stay within the bounds of the Constitution and the law. This task is explicit in section 165 (1) (c) of the Constitution which stipulates that, the role of the courts is paramount in safeguarding human rights and the rule of law. In addition, section 164 of the Constitution provides that courts are independent and only subject to the Constitution and no one is permitted to interfere in the discharge of their judicial functions (Constitution 2013 section 164). Section 164 (2) (b) of the Constitution further places an obligation on the state to protect and assist the judiciary in carrying out its functions effectively, particularly to ensure that all court orders are obeyed. As a result, the courts in Zimbabwe, particularly the new Constitutional Court (ZCC) must recognise its primary role as that of deepening constitutional democracy, upholding the protection of human rights and entrenching the rule of law. The ZCC has a duty to ensure that it interprets all laws in line with the Constitution particularly the Bill of Rights. The Constitution provides for constitutional democracy mechanisms such as rule of law, constitutional supremacy and entrenched 
fundamental rights. However, the effectiveness of these mechanisms lies in their enforcement through an independent and impartial judiciary.

The subservience of all organs of state to the Constitution by requiring that they constantly justify their actions in terms of the Constitution potentially places the courts on a path of conflict with the political branches of government. This is likely to be contested by these political branches as to the extent of courts' functions and roles under the Constitution. The duty of the courts is to ensure that the elected branches of government adhere to the Constitution and the law hence the subordination of these political organs. This subordination however, is particularly relevant with regard to the protection of rule of law, separation of powers and most of all the protection and the adjudication of all rights including socio-economic rights. Nevertheless, the subordination of the political branches of government to the judiciary may entail the interference in policy choices by the judiciary which might fall foul of the doctrine of separation of powers. Writing in the South African context, the late former Chief Justice (CJ) of South Africa, Justice Pius Langa cautioned that judges are not law-makers and thus must be careful in being over active or passive in socio-economic rights matters( Langa 2006:10-11). However, Langa CJ was also quick to recognise the prominent role of the judiciary in a constitutional democracy, that where there is need to align the laws and government conduct with the Constitution, the judiciary to a certain extent, do legislate and as such must fulfil the mandate (Langa 2006).

The judgement of the Supreme Court of Zimbabwe in Zimnat Insurance Co Ltd $v$ Chawanda (Zimnat Insurance case) further highlighted the special role of the judiciary in developing countries such as Zimbabwe. The Zimbabwe Supreme Court reasoned that:

Today, the expectations among people all over the world and particularly in developing countries are rising and the judicial process has a vital role to play in moulding and developing the process of social change. The judiciary can and must operate the law to fulfil the necessary role of effecting such development. It sometimes happens that the goal of social and economic change is reached more quickly through legal development by the judiciary than by the legislature. This is because judges have a certain amount of freedom of latitude in the process of interpretation and application of the law (Zimnat Insurance case). 
The Role of Courts in Enforcement of Socio-Economic Rights: 2013 Constitution of Zimbabwe 33

Accordingly, the judiciary must understand its constitutional duty and ensure that constitutionally protected socio-economic rights become a reality through a generous contextual interpretation that gives content to these rights.

Therefore, the broad range of socio-economic rights in the Constitution present the courts with an important opportunity to develop the legal system to be more attuned to poverty, social marginalisation and respect for human dignity and fundamental rights (Zimnat Insurance 1991 case). Additionally, these rights present the judiciary with an important opportunity to re-establish itself as one of the true upholders of human rights in Africa. This is because when the people have exhausted all the avenues in the protection of their rights; they will turn to the courts to act as their institutional voice and last resort. It follows that judges must shy away from highly structured interpretation of rights and adopt a policy-oriented and substantive legal reasoning that promotes the protection of socio-economic rights (Klare 1998:168).

For example, recently, the High Court in Harare granted temporary injunctions to halt evictions of people and destruction of people's homes in Mazoe by the government (All Africa.com 2014). These positive orders were granted after the Zimbabwe Lawyers for Human Rights (ZLHR) argued that the Constitution provides for a right not to be evicted without a court order (Constitution 2013:section 74), which in essence protects the right to shelter. This is a sign that the courts are positioning themselves as a key player in the domestic framework for protecting the poor and the marginalised against arbitrary and excessive bureaucratic actions.

It is thus contended that courts must use their wide judicial powers to give social justice to the poor and economically and socially disadvantaged. Such remit include powers to grant appropriate and equitable remedies, powers to determine the constitutionality of any legislation and conduct, including powers to develop the common law or customary law in line with the parameters of the Constitution (Constitution 2013). This is because in interpreting socio-economic rights provisions under the Constitution, judges and indeed the entire judiciary cannot remain aloof from social and economic needs of the vulnerable and impoverished. Accordingly, through their activism, judges must nudge the government to move forward and improve the social and economic conditions of the poor (Dumbutshena 1998:188). This way the government will be able to respect the socio-economic provisions in the Constitution and fulfil its obligations. Justice Ajibola (1998) puts it in the following words: 
We as African judges must firmly uphold our constitutions and the rights of all our citizens... If we should fail in our duty, society may not take our judgements seriously and posterity may not forgive us. Confidence in the judiciary could vanish. Respect for law and order may diminish and even break down. If it should, anarchy would take over. People may take law into their hands and violence would be the order of the day.

It follows that the protected rights present the judiciary with an important opportunity to recreate its image as the upholder and guardian of human rights. The judiciary must adopt new ways of thinking and innovative ways to engage with the new Constitution. For example section 165 (7) of the Constitution mandates judges to take reasonable measures to maintain and enhance their professional knowhow, skills and qualities and in particular keep themselves abreast with developments in domestic and international law. Additionally, courts must shy away from legal formalism and be forward-looking and position themselves as the true upholders of the Constitution and the law, and ensure that vulnerable groups enjoy the constitutionally protected rights (Constitution 2013). As such, the Bill of Rights is particularly significant as it creates the possibility for ordinary, poor and disadvantaged communities to challenge the exercise of public power that undermine their rights (Liebenberg 2010:34). In addition, it is important to state that, all the effective protection of all constitutional protected rights is dependent on the strength of the judiciary which in turn lies on the impartiality and independence thereof (Mavedzenge \& Coltart 2014). Accordingly the judiciary must be free from all executive and political pressures. The next section discusses the manner in which constitutionally protected socio-economic rights should be interpreted by the courts.

\section{Interpreting socio-economic rights: the role of underlying values}

The Constitution is founded on very important values. These include the values of human dignity, openness, justice, equality and freedom (Constitution 2013). The values in the Constitution play an important role in interpreting socio-economic rights if these rights are to amount to legal rights enforceable in a court of law. Section 46 of the Constitution is important in this regard. Section 46 (1) (a) provides that, when interpreting the rights in the Bill of Rights, courts and any other similar forum, must give 
full effect to all the rights and freedoms enshrined in the Constitution. Of importance is section 46 (1) (b) which stipulates that when interpreting protected rights, courts and similar bodies must promote the values that underlie a democratic society based on human dignity, openness, justice, equality, and freedom and in particular, the values and principles set out in section 3 of the Constitution. Section 3 provides that Zimbabwe is founded on the respect of the following values and principles, supremacy of the Constitution, rule of law, fundamental rights and freedoms, inherent dignity and human worth and equality of all among others (Constitution 2013). Liebenberg explains that human dignity as a value further requires a burden of justification to be placed on the state in cases involving a deprivation of human needs (Liebenberg 2005:1-32). Accordingly, section 3 constitutes an endorsement by the Constitution to the values of democracy, human dignity, equality and freedom in the interpretation of all constitutionally protected rights in the Bill of Rights including socio-economic rights. For this reason, section 46 enjoins the courts to play an active role in promoting those values in their interpretative and adjudicative roles in socio-economic rights cases.

It is thus important for the courts in their interpretation of socio-economic rights provisions in the Bill of Rights to execute their constitutional mandate in a way that promotes and gives substantive meaning to the founding values enunciated in section 3 . This is because the status of socio-economic rights as justiciable rights in the Constitution vests in the judiciary an important role in interpreting these rights taking into context founding values that underlie a democratic society (Constitution 2013). Furthermore, the judiciary is mandated to ensure a contextual interpretation that pays due regard to the historical background and all the provisions of the Constitution particularly the values and national objectives in Chapter 2 of the Constitution (Constitution 2013). The next section discusses the importance of international law and foreign law as interpretative tools.

\section{Interpreting socio-economic rights: international law as an interpretive tool}

International law forms part of Zimbabwean law only when it has been incorporated into domestic law through an Act of parliament (Constitution 2013). This means that Zimbabwe is a dualist state as opposed to a monist state. Dualism stresses that, "international and municipal law differ so radically in the matter of subjects of the law, 
its sources and its substance, that a rule of the international law can never per se become a part of the law of the land; it must be made so by the express or implied authority of the state" (Dugard 2011:42) Monism provides that international law applies directly in the domestic legal order without the need for incorporation (Dugard 2011). Dualism under the 2013 Constitution is evident from a number of constitutional provisions. Notably, section 34 of the Constitution calls for the domestication of international instruments and specifically stipulates that the state must ensure that all international conventions, treaties and agreements to which Zimbabwe is a party are incorporated into domestic law. Section 327 of the Constitution further echoes the fact that Zimbabwe is a dualist state. Section 327 (2) (a) provides that an international treaty does not bind Zimbabwe until it has been approved by parliament and does not form part of the law of Zimbabwe unless it has been incorporated into the law through an Act of parliament. However, in contrast, customary international law forms part of the law of Zimbabwe unless it is inconsistent with the Constitution and an Act of parliament (Constitution 2013).

Despite adopting the dualist approach towards international treaties, the 2013 Constitution demonstrates a clear determination to ensure that Zimbabwean laws and the Constitution itself should be interpreted to comply with international laws, particularly in the field of human rights. The Bill of Rights refers directly to international law and thus must be subjected to a special interpretative regime which pays due regard to international law. Section 46 (1) (c) of the Constitution requires that when interpreting the Bill of Rights, courts must take into account international law and all treaties and Conventions which Zimbabwe is a party to in their rights interpretation.

The effect of section 46 is that Zimbabwean courts are obliged to make use of and have recourse to international instruments and interpretative guidance of quasi-judicial bodies established under such international instruments in their judicial enforcement of socio-economic rights. In essence, section 46 of the Constitution "signals the Constitution's openness and receptiveness to the norms and values of the international community" (Liebenberg 2010:101). In addition, section 46 expresses Zimbabwe's aspiration to be part of the international community, to adhere to its normative standards and to contribute to the development of international law based on domestic experiences of human rights (Liebenberg 2010:101). Despite Zimbabwe being a dualist state, the use of international law for the purposes of interpreting the Bill of Rights in 
The Role of Courts in Enforcement of Socio-Economic Rights: 2013 Constitution of Zimbabwe 37

terms of section 46 must be distinguished from the binding status of international law in domestic law; in that, courts must refer to both binding and non-binding international instruments. This is because section 46 of the Constitution refers to interpretive guides which the courts must take into account but not bound to follow (Constitution 2013).

For a meaningful interpretation, it is argued that such international law must include both binding and non-binding international law to the extent that it is not contrary to the integrity and spirit of the Constitution (de Bourbon 2003). This means that for better interpretation of rights, courts are enjoined to consider not only binding instruments but also to take into account those principles laid down in conventions to which Zimbabwe is not a party to. These include the European Convention on Human Rights and Fundamental Freedoms and the American Convention on Human Rights and General Comments by treaty bodies which are not binding but instead provide guidance and clarity on the nature, content and scope of socio-economic rights ( $S$ v Juvenile 1989). Such interpretation is to inform a substantive and generous interpretation of socioeconomic rights that provides guidance and purpose taking into account international human rights law norms. In General Comment 9 on the domestic application of the Covenant, the Committee on Economic Social and Cultural Rights (CESCR) stipulated that, legally binding international human rights standards should operate directly and immediately within the domestic legal system of each state party, thereby enabling individuals to seek enforcement of their rights before national courts and similar forums (Constitution 2013).

In the past, Zimbabwean courts have been willing to refer to international law in interpreting rights. The ZCC recently illustrated that it is also adopting a flexible and generous approach towards international human rights instruments in a case that involved the right to freedom of expression. In the case of Nevanji Madanhire, Nqaba Matshazi v Attorney-General of Zimbabwe, the ZCC referred to a number of international law instruments as interpretative tools in its adjudication of the case. The court referred to the International Covenant on Civil and Political Rights, United Nations Resolutions, and the Human Rights Committee General Comment 34 in its determination of the case.

International human rights law norms are of significance to Zimbabwe in that justiciable socio-economic rights are new provisions in the Constitution. Hence, international law and agreements protecting socio-economic rights as justiciable rights will be a useful guide in the process of interpreting these rights by our courts. This 
resonates with section 12 (1) (b) of the Constitution, which provides that, respect for international law must form the basis of Zimbabwean foreign policy. This further echoes with section 327 (6) of the Constitution which provides that, when interpreting any legislation, every court and tribunal must adopt a reasonable interpretation of the legislation that is consistent with any international convention, treaty or agreement which is binding on Zimbabwe, in preference to an alternative interpretation inconsistent with that convention treaty or agreement (Constitution 2013). The same message is echoed in section 326 (2) of the Constitution with regard to customary international law Thus, legislation that affects people's socio-economic rights should be interpreted, as far as reasonably possible, to be in conformity with applicable international law such as the ICESCR and the African Charter, among others (Liebenberg 2010:105). This provides additional impetus for the courts to interpret socio-economic legislation in ways that take into account widely accepted international normative values and principles (Liebenberg 2010). For that reason, courts must understand the process of interpreting and giving full force and effect to human rights norms as a dialogic process which includes a range of national and international actors and principles (Liebenberg 2010). This suasion informs the courts, especially the $(Z C C)$ to inculcate a culture of inclusive interpretation of socio-economic rights taking into account relevant principles of international human rights law. The next part discusses foreign law as an interpretative guide.

\section{Interpreting socio-economic rights: comparative foreign law as an interpretative tool}

Section 46 (1) (e) of the Constitution provides that, when interpreting the Bill of Rights, courts may refer to relevant foreign law. This is different from the international law provision which appears peremptory as compared to foreign law which appears as affording discretion on the judges. Liebenberg commenting on a similar provision under the 1996 South African Constitution argues that, despite many criticisms against application of foreign law and judgments both positive and negative, foreign law offers many opportunities that deepen and enrich constitutional jurisprudence (Liebenberg 2010:119). This is a sign of globalisation and universalism where the meaning accorded to fundamental human rights norms may be influenced by a cross-cultural dialogue extending across national boundaries (Kapindu 2013). Roach opines that "a globalised 
The Role of Courts in Enforcement of Socio-Economic Rights: 2013 Constitution of Zimbabwe 39

world is one where people, including judges, engage in the multiple and on-going conversations across borders. It is hopefully a world characterised by a sense of openness, modesty and willingness to learn from others" (Roach 2012). Thus, recourse to foreign law as an interpretive guide is significant to the courts acting under the 2013 Constitution, particularly in the process of interpreting socio-economic rights. This is because socio-economic rights have been marginalised for a long time and lot of conceptual and practical challenges arise in adjudicating these rights. These challenges include institutional competence of the courts, separation of powers, nature and content of these rights, model of review, and remedial framework among others. Courts in Zimbabwe must therefore be willing and ready to learn from experiences, pitfalls, challenges and successes of similarly placed jurisdictions, particularly South Africa with its constitutionally entrenched socio-economic rights. This is because socio-economic provisions in the Constitution may have been inspired by the similar provisions in the 1996 South African Constitution. Due to a shared common law heritage, our courts have always referred and cited South African judgements and our courts are expected to cite socio-economic rights from that jurisdiction for interpretative purposes. In the Nevanjie case, the ZCC cited relevant foreign law albeit not in relation to socio-economic rights. The ZCC referred to the South African case of Hoho $v$ The State in interpreting the right to freedom of expression.

\section{Purposive interpretation through the prism of the Bill of Rights}

Section 46 (2) of the Constitution provides that when interpreting any legislation and when developing common law or customary law, every court must promote and be guided by the spirit and objectives of the Bill of Rights. The directive contained in section 46 (2) of the Constitution makes it clear that legislation, common law and customary law fall within the ambit of the entire Bill of Rights and the Constitution itself ( $S$ v Makwanyane 1995 para 109). Put differently, the Constitution is the supreme law through which all law must be tested and in particular all laws should be measured through the prism of the Bill of Rights. The consequence of this provision is that any law that is retrogressive in regard to the enforcement and implementation of socioeconomic rights in the Constitution would not pass constitutional muster and must be declared invalid. 
Socio-economic rights are new in the Constitution compared to civil and political rights that have been a feature in the LHC since 1980. Consequently, these rights ought to be approached with a purposive, objective and substantive interpretation that allows for their full and effective protection through the courts. Otherwise any formalistic and rigid approach detracts from the object, purpose and spirit of the Bill of Rights. In Bull $v$ Minister of Home Affairs (Bull case), the Zimbabwe Supreme Court (ZSC) held that while courts must always address themselves to the actual language used in a constitutional provision, narrow and pedantic interpretations must be avoided (Bull case 1986). This is consistent with human rights provisions which must be construed generously and purposively so as to eschew the austerity of tabulated legalism (Rattigan case 1995).

The purposive approach will often be one which calls for a generous interpretation to be given to a right to ensure that individuals secure the full protection of the Bill of Rights (Soobramaney case para 17). This was echoed in the case of In Re Munhumeso and Others (1995). In that case, the ZSC held that all constitutional provisions bearing upon a particular subject are to be considered together and construed as a whole in order to give effect to the objective and purpose of the constitutionally protected rights. However, this is not always the case, and the context may indicate that, to give effect to the purpose of a particular provision, a narrower or specific meaning should be given to it.

Under the 2013 Constitution, courts bear the primary obligation to ensure that socio-economic rights are interpreted in a way that responds to the demands of the Bill of Rights and the socio-economic needs of the people, especially the disadvantaged, indigent and impoverished. This is in line with the argument by the late former Chief Justice Dumbutshena who argued that the judiciary in a developing country should play an activist role in transforming the society (Dumbutshena 1998). Dumbutshena further stated that the judiciary has the opportunity to create social justice in society and that justice can help to transform the socio-economic needs of the disadvantaged ones (Dumbutshena 1998). Of importance is the point Dumbutshena makes that courts can transform societies if they accept judicial activism as a way of promoting justice, equality and social justice (Dumbutshena 1998). Consequently, under the Constitution, courts are one of the key institutional players in the transformative process from that of socioeconomic deprivation to that of equal distribution of resources. This will be done, if the courts adopt new concepts of justice and means of interpretation of rights that will 
The Role of Courts in Enforcement of Socio-Economic Rights: 2013 Constitution of Zimbabwe 41

enable disadvantaged societies and vulnerable groups to live full lives and to share the benefits of the socio-economic resources. In the process of interpreting socio-economic rights courts must choose a model of review that appropriately gives effect to the protected rights. The next section explores the model of review provided for under the 2013 Constitution.

\section{MODEL OF REVIEW UNDER THE 2013 CONSTITUTION Reasonableness approach}

The Constitution refers to the realisation of socio-economic rights through "reasonable legislative and other measures" (Constitution 2013). In the Grootboom judgment, the Constitutional Court of South Africa explained what the reasonableness approach entails. That Court held that, in reviewing the positive duties imposed by socio-economic rights provisions on the state, the central question that the court asks is whether the means chosen are reasonably capable of facilitating the realisation of the socio-economic rights in question. In the words of the Court, "a court considering reasonableness will not enquire whether other more desirable or favourable measures could have been adopted or whether public money could have been better spent. The question would be whether the measures that have been adopted are reasonable" (Grootboom case 2000).

The socio-economic provisions under the Constitution provides for negative and positive duties for Zimbabwe (Constitution 2013). The Constitution in section 44 places an overarching obligation on the state to respect, promote, protect and fulfil the rights in the Bill of Rights (Constitution 2013). Section 44 of Constitution establishes that all rights in the Bill or Rights impose a combination of negative and positive duties on the state. Negative duties impose on the state the obligation not to interfere with the existing socio-economic rights. Positive duties are explicit from the qualification of these rights which requires the state to "take reasonable and others measures, within its available resources, to achieve the progressive realisation of these rights." For instance section 74 (1) of the Constitution provides for the right of access to healthcare while section 74 (4) internally limits it. However this right in subsection 1 by providing for a positive duty on the state to take reasonable legislative and other measures, within the limits of available resources to achieve the progressive realisation of the right to health. Thus, through their positive nature, socio-economic rights in the Constitution present the Zimbabwean courts with a number of practical challenges. Firstly to define the specific 
content of socio-economic rights as protected in the Constitution and secondly to issue out appropriate remedies for the violation of these rights.

\section{Reasonableness as interpreted by South African Courts}

Since the Bill of Rights in the 2013 Constitution is modelled along that of the 1996 South African Constitution, it is important to draw lessons from the jurisprudence of that country on how courts in that jurisdiction have applied reasonableness as the model of review of positive duties imposed by socio-economic rights. The Constitutional Court of South Africa adopted the reasonableness model in a number of its first socio-economic rights cases and these include the Government of Republic of South Africa and Others $v$ Grootboom and others (Grootboom case), Minister of Health and Others $v$ Treatment Action Campaign (TAC) cases, and Khosa and others $v$ Minister of Social Development. For example in the TAC case, the Constitutional Court of South Africa held that the failure to take measures by the state without delay to permit and facilitate the use of anti-retroviral drug Nevirapine throughout public health care facilities in South Africa for the purposes of preventing mother to child transmission (MTCT) of HIV was unreasonable as it violated the right to healthcare in that country (TAC case 2002). In the Grootboom case, the housing programme was declared to be unreasonable for its failure to provide relief for people who have no access to land, no roof on their heads, and who were living in deplorable conditions (Grootboom case 2000). In essence, the focus of the Constitutional Court of South Africa has been limited to evaluating the reasonableness of the government programmes while explicitly rejected the minimum core approach.

Although some scholars have highly criticised reasonableness as a model of review for socio-economic rights, it fits well with the doctrine of separation of powers and has brought some positive changes in jurisdictions where it has been applied. Liebenberg has however suggested means in which reasonableness approach could be strengthened especially in respect of vulnerable groups who often lack access to essential socioeconomic services (Liebenberg et al, 2010: 83).

Firstly, vulnerable litigants seeking access to socio-economic rights may benefit from having the burden of proving the reasonableness of government measures placed on the state (Liebenberg 2010:83). In essence, this will give a presumption of unreasonableness of government measures in circumstances where individuals and groups cannot gain access to basic necessities of life. Thus, the obligation and onus 
The Role of Courts in Enforcement of Socio-Economic Rights: 2013 Constitution of Zimbabwe 43

would be on the government to justify why the exclusion is reasonable in any given circumstances. Second, the reasonableness review standard could be strengthened by requiring a compelling government purpose for failure to ensure that vulnerable groups have access to basic needs (Liebenberg 2010:83). The political branches must be required to demonstrate through evidence and argument to the courts that its resources are inadequate and thus unable to fulfil constitutional obligations. Liebenberg has argued that it is not sufficient for the courts to assert that it is impossible to give everyone access to a core service immediately (Liebenberg et al 2010). Instead, the government must show that it has good reasons for failing to meet its constitutional obligations (Liebenberg et al 2010). Likewise, it is argued in this study that Zimbabwean courts would be required to scrutinise all the evidence provided by the government with a view of assessing whether it presents a compelling justification for failing to provide basic needs. Lastly, even though the government may justify its failure to meet its socioeconomic obligations, it should also show that there are no less restrictive means of achieving its purposes that limits access to essential levels of the socio-economic rights (Liebenberg et al 2010:84). It follows from the above that if our courts adopt the reasonableness approach as the model to review government programmes and policies in respect of giving effect to constitutionally protected socio-economic rights, courts must ensure that this approach acts as a yardstick through which courts measure the conduct of the government in fulfilling socio-economic obligations in the Constitution.

Furthermore, courts considering socio-economic rights cases in other jurisdictions have employed many of the reasonableness tests commonly used in administrative law, comparing the seriousness of the violation of a right with the importance of the state justification. Therefore the concept of reasonableness, if adopted by the courts in Zimbabwe, must operate as a standard for the government to conduct policy and draft legislation that will promote the protection and realisation of socio-economic rights. The approach must be used by the courts to assess governmental conduct (Coomans 2005:15). Where government does not meet the required constitutional standard of reasonableness, courts must require the government, to revise its policy to provide for those in need and to remove anomalous restrictions. Accordingly, the most important point under the reasonableness approach is that the government justifications will be subject to scrutiny by the courts and in turn the government must present convincing reasons why particular sectors of the society are excluded from accessing basic socio- 
economic services (Liebenberg et al 2010:82). This will inculcate a culture of justification which is one of the underlying principles of constitutional review.

The standard of scrutiny that must be employed by the courts in Zimbabwe must be more than simply enquiring whether the policy was rationally conceived and applied in good faith (Liebenberg 2010:84). For example in the Grootboom and TAC cases, the South African Constitutional Court indicated that evidence in particular cases may show that there is a minimum core of the particular service that should be taken into account in determining whether the measures adopted by the state are reasonable. Accordingly, the reasonableness approach must go beyond the scrutiny of the adopted measures and enquire into the degree and extent of the denial of the socio-economic right (Grootboom case 200: para 33). Furthermore, such an approach must incorporate two interests protected by socio-economic rights. Firstly, in determining whether the means provided for realising of socio-economic rights are reasonable, the courts in Zimbabwe must ensure that measures put in place by the government cater for the more basic interest of survival (Bilchitz 2002:490). Secondly, the courts must ensure that the medium and long term measures towards the realisation of socio-economic rights are extensive and extend beyond the mere survival and basic needs (Bilchitz 2002:490).

South African courts, adjudicating on similar constitutional provisions to ours, have set out the following standard for government measures and programmes to be reasonable:

- The government programmes must be comprehensive coherent, coordinated,

- they must be balanced and flexible, and make appropriate provision for short, medium and long term needs,

- they must be reasonably conceived and implemented, and

- they must be transparent, and the contents must be made known to the public (Grootboom case 2000 para 33-43).

The consequences of the reasonable test is that the applicants are not entitled to immediate relief, rather they are entitled to reasonable action by the state that will place them in a position to receive the tangible goods and services, for instance, the provision of Nevirapine in the TAC case. The next section discusses another possible model, the minimum core approach. 
The Role of Courts in Enforcement of Socio-Economic Rights: 2013 Constitution of Zimbabwe 45

\section{Minimum core obligation}

The minimum core obligation is defined as the threshold which all states must meet immediately in the process of realising socio-economic rights (TAC case para 10). In terms of the minimum core obligation, there lies an obligation to ensure the satisfaction of at the very least, minimum essential levels of the rights that are incumbent upon each state party to the ICESCR. The minimum core which is espoused in the CESCR's General Comment 3, provides that a state party in which any significant number of people is deprived of essential foodstuffs, essential primary healthcare, basic shelter and housing or of the most basic forms of education is prima facie failing to discharge its obligations under the ICESCR (UN CESCR 1991 para 3). The minimum core concept suggests that there are degrees of fulfilment of a right and that a certain minimum level of fulfilment takes priority over a more extensive realisation of the right (Chowdhury 2009). In essence, this approach appreciates that everyone must be subjected to life that upholds his/her dignity. Bilchitz observes that the purpose of the minimum core obligations approach is to ensure that regardless of resources, people have access to basic needs required for survival (Bilchitz 2003:13-15). It is worth noting however that resource availability remains a paramount determinant of the proper and effective protection and implementation of socio-economic rights.

Some scholars have stated that the minimum core approach is the better model of review in protecting and implementing socio-economic rights compared to the reasonableness approach which is provided for under the Constitution (Blichitz 2003). This is because instead of questioning the reasonableness of the state measures for realising these rights, it speaks to the real content of the specific rights. Furthermore, the scholars who support the minimum core approach argue that this approach gives a better understanding to the government as to what obligations arise from each legal right and in turn enable individuals to hold the government accountable for not meeting the minimum guaranteed by a legal right (Chowdhury 2009).

It must however be noted that in practice, it has not been the case. South Africa for example has rejected this approach as being rigid and vague. The minimum core approach seems problematic because it disregards the constitutional requirement that internal qualification of socio-economic rights maybe realised progressively taking into account available resources (Young 2008). This is opposite to the reasonableness approach that is influenced by two factors. The factors include the internal qualification 
of socio-economic rights that these rights are subject to progressive realisation taking into consideration of available resources, and secondly that reasonableness is judged in the light of the social, economic and historical context and considerations (Liebenberg et a/ 2010). These two factors that underlie reasonableness approach appreciate that socioeconomic rights cannot be realised immediately where resources do not allow for that. Socio-economic rights in the Constitution are internally qualified as subsections of these rights makes it clear that the obligation imposed by socio-economic rights are defined by three key elements and these are "the obligation to take reasonable measures," "to achieve the progressive realisation" of the rights, "within available resources" (Constitution 2013).

The minimum core as with the reasonableness approach has its own limitations and our courts must be careful in over emphasising this approach (Young 2008). For example, Liebenberg highlights a number of difficulties posed by the minimum core approach. These include, the approach's impact on democratic institutional functioning (including supposed infringement by courts on separation of powers and participatory democracy), its linkage to survival standard does not guarantee clarity and certainty in defining priority claims and the standard is unduly reductionist in the context of a transformative constitutionalism which seeks to promote the achievement of social justice (Liebenberg 2008).

Additionally, the minimum core approach has been labelled as rigid and plagued by complexities and inherent paradoxes and thus adopting such an approach may bring more confusion than solutions (Young 2008). The Constitutional Court of South Africa in the Grootboom case argued that, it is not clear whether the minimum core obligations should be defined with reference to specific groups or generally. Additionally, some of the reasons of the rejection of this approach by the Constitution Court of South Africa are in relation to its incompatibility with the institutional competencies of the courts in budgetary matters (TAC case para 70-71). However, the rejection of the minimum core obligation as a model of review and the adoption of the reasonableness approach by the Constitutional Court of South Africa has invited a lot of criticism from academic scholars. Dugard and Wilson for example provides that,

What the Court has been reluctant to do since Grootboom case is to exercise the power the Constitution assigns it explicitly to determine the 
The Role of Courts in Enforcement of Socio-Economic Rights: 2013 Constitution of Zimbabwe 47

interests socio-economic rights themselves exist to protect and advance.

Reasonableness and procedural fairness are not sufficient to define these

interests. They simply act as a prism through which the enforceability of these interests can be considered on the facts of a particular case. At best, they simply embroider the entitlements already guaranteed in Section 33 of the Constitution (Dugard \& Wilson 2011).

Nonetheless as held in the South African case of Grootboom in certain instances, minimum core will be a strong determinant of the reasonableness of the steps taken by the government. This way courts will be able to overcome the problem earlier identified, which is that of defining the precise content of the protected socio-economic rights. Furthermore, courts will be able to ensure that no one is deprived of the floor base levels of the constitutionally protected rights. In instances where people are deprived of the basic necessities of life, courts must ensure that the government has taken all practical and reasonable measures to remedy the situation (UN CESCR 1991).

Despite the inadequacies of the two models discussed above, our courts must position themselves as to the proper model of review to ensure that the duties imposed by the constitutionally protected socio-economic rights are fulfilled. This is because for the judiciary acting under the Constitution particularly socio-economic rights is a constitutional invitation to engage in transformative constitutionalism, from a pre and post-colonial injustices to a more just society where there is equal distribution of resources. Accordingly, the inclusion of the long marginalised socio-economic rights in the Constitution is intended at advancing the plight and socio-economic life of the people to uplift their dignity. Although the Constitution does not mention the minimum core, the inclusion of socio-economic rights itself is an endorsement that the Constitution aims to transform the Zimbabwean society from a society based on socioeconomic deprivation to the one based on equal distribution of resources to all. In essence, it is aimed at transforming their lives for the better. Thus, it is not possible to respect people's dignity while denying them, at the very least, the basic needs for human survival.

\section{Integrated approach}

The judiciary in Zimbabwe should draw understanding of its role in enforcing socioeconomic rights vis-à-vis the doctrine of separation of powers. The courts must consider 
adopting an integrated approach that will enhance the realisation of rights. Such an approach employs both reasonableness approach and the minimum core approach. This is because on one hand, the text of the Constitution refers to "reasonable legislative and other measures" and on the other the Constitution espouses values of human dignity, equality and freedom that signify that no one must be denied of the basic necessities of life.

Furthermore, the Optional Protocol to the ICESCR (OPT-ICESCR) seems to endorse both "reasonableness" and minimum core approaches, an indication that these are not mutually exclusive but can be employed together to comprehensively and mutually support each other with the result that socio-economic rights are effectively implemented and realised (UN Opt-Protocol 2008). In particular, article 8 (4) of the OPTICESCR provides that, "when examining communications... the Committee, shall consider the reasonableness of the steps taken by the state party to the ICESCR. In doing so, the committee shall bear in mind that the state party may adopt a range of possible policy measures for the implementation of socio-economic rights." While it is appreciated that domestic courts do not have the advantage to access the extensive material for state reports received by the CESCR, adopting an integrated approach which is inclusive of both minimum core and reasonableness approach will help the courts define the constitutionally protected rights in precise terms including the basic minimum essentials for a dignified life (Orago 2013). This will further ensure that the entrenched socioeconomic rights have practical benefits for the worse off in society. In addition, an integrated approach will breathe life into the abstract socio-economic provisions and ensure that the state has clear guidelines within which to structure its legislative, policy and programmatic implementation framework (Orago 2013).

At the end of court's adjudication of socio-economic rights, particularly where the court makes an order in favour of the applicant, the next step is to craft an appropriate remedy. This is significant in the rights discourse because individuals do not litigate human rights for nothing. They litigate to repair harm caused and in respect of socioeconomic rights to deter future violations as well. The next section explores the remedial framework provided for in the Constitution. 
The Role of Courts in Enforcement of Socio-Economic Rights: 2013 Constitution of Zimbabwe 49

\section{Remedial framework: crafting judicial remedies for violations of socio-economic rights}

Another challenge that is likely to face Zimbabwean courts under the new Constitution is to craft appropriate remedies for the violations of socio-economic rights. Section 175 (6) (b) of the Constitution gives Zimbabwean courts the power to make any order that is just and equitable, including an order limiting the retrospective effect of the declaration of invalidity for any period to allow the competent authority to correct the defect (Constitution 2013). It is contended that the test for the effectiveness of the court's remedies, under this new Constitution is whether the remedy is appropriate. Appropriate relief thus constitutes any suitable remedy that is just and equitable. In addition section 85 of the Constitution stipulates that, a court may grant appropriate relief including a declaration of rights and an award of compensation.

Thus, once the courts have completed adjudicating socio-economic rights claims, a constitutional duty that arises is that of crafting an appropriate remedy. This is consistent with the very notion of human rights that relief should be accorded to all whose rights are violated. Furthermore, crafting judicial remedies is the most significant part of the judicial process because litigants do not litigate rights just for the sake of it, but rather to seek relief or redress that will vindicate their rights (Biegon 2012). Awarding remedies for violations of civil and political rights is relatively easy since the nature of these violations simply requires that the victim be put in the position he would have been in were it not for the violation (Mbazira 2009). As has been the trend in Zimbabwe and indeed in other jurisdictions, this requires mainly compensatory orders such as damages. It must however be noted that, awarding remedies for violations of socio-economic rights is more complex. This is because socio-economic violations are systemic in nature and often reflect underlying structural failures that result in historical denial of rights for large numbers of individuals and groups (Biegon 2009). Therefore, Zimbabwean courts need to craft appropriate remedies in respect of socio-economic rights that will have a wider impact, touching on and transforming the lives of both the litigants and similarly suitable for people who are not before the courts.

The choice of the remedies by the courts will be influenced by two theories of justice, namely corrective and distributive justice theories. On one hand, the corrective justice theory focuses on the restoration of the victims to their positions had it not been for the violation whereas distributive justice, on the other hand, is manifested in distribution of 
resources (Mbazira 2009). Thus distributive justice theory is more suitable to be applied in socio-economic rights cases. This is because courts relying on distributive justice look beyond the interests of the parties before it to the larger picture, the future and on the plight, needs and interests of the community as a whole (Mbazira 2009). In such cases, courts are thus capable of crafting remedies while taking into account factors that may impact on the implementation of such remedies.

The Constitution does not explicitly provide for a blue-print distributive justice theory. Nevertheless, an argument may be advanced that the Constitution ascribe to the distributive justice theory. This is because it protects socio-economic rights and it is founded on significant values of human dignity, social justice, openness and equality. These values inform the distributive justice theory in that they are meant to ensure equal distribution of resources. Section 3 (2) (j) of the Constitution also stipulates that there must be fair and equal distribution of national resources including land. Thus, in respect of socio-economic rights, our courts must craft remedies that respond to people's needs, poverty, resource deprivation and social marginalisation. In essence, the range of remedies that our courts will craft to remedy violations of socio-economic rights must accustom to a distributive conception of justice. Additionally, the judiciary must utilise this opportunity to forge new tools and shape innovative remedies where necessary, to ensure socio-economic rights are well protected and enforced.

The crucial decision for courts in Zimbabwe is whether to rely on declaratory relief or injunctions to enforce socio-economic rights. Declarations are based on good faith and to ensure compliance with the Constitution, courts assume that government will take prompt measures without the need of judiciary intervention (Roach 2010:113). Sections 175 (6) (b) and section 85 of the Constitution discussed above seem to endorse declaratory relief as a form of remedy. What is apparent from these two sections is that the Constitution does not refer to injunctions as a form of a remedy. Declarations proceed on the assumption that governments will take prompt and competent steps to comply with courts' declarations of constitutional entitlements and that continued supervision and subsequent intervention by the courts will not be necessary to ensure compliance with the Constitution. A declaration of constitutional entitlement will often be made in general terms allowing governments' considerable flexibility and latitude in selecting the precise means to be used (Roach 2010). Conversely, injunctions (structural) generally contemplate the possibility of continued judicial involvement (Roach 2010). 
The Role of Courts in Enforcement of Socio-Economic Rights: 2013 Constitution of Zimbabwe 51

This is because they are ultimately enforceable through contempt proceedings that can result in the imposition of fines or even jailing of government officials. Unlike declarations, injunctions are specifically worded and require government to report back.

The Constitution gives courts very wide remedial powers to grant appropriate relief for any constitutional violation including the violation of socio-economic rights. Many scholars agree that structural interdicts are the most effective remedies for violation of socio-economic rights, especially where the state has a long history of non-compliance with court decisions (Liebenberg 2010:426; Roach 2010:113)). This is because courts retain supervisory jurisdiction over the implementation of their decisions and thus Zimbabwean courts must consider using structural injunctions. Injunctions (particularly structural) require the government to report back to the court at regular intervals about the steps taken to comply with the Constitution. The court orders the respondent to report back to it on the implementation of its decision and as such allows courts to oversee progressive protection of socio-economic rights. For that reason, Zimbabwean courts must not only limit themselves to declarations as the form of just, appropriate and equitable remedy but grant any appropriate relief that is capable of securing the protection, fulfilment and enforcement of the rights in question. In certain instances, more innovative remedies may have to be developed to vindicate the Constitution.

Roach has however argued that courts must be careful in issuing such mandatory orders and thus should focus on the broad principles that guide the exercise of remedial discretion and not attempt to construct rigid rules or categories for the exercise of such discretion (Roach 2010). Such a careful consideration by the courts will allow courts to respect the separation of powers by not usurping the powers of the political branches of government. Nevertheless, as was stated above that, courts in the new constitutional democracy, acquire a more active role. Therefore, where there is need to bring about compliance with the demands and needs of the Constitution, Zimbabwean courts must issue appropriate relief that is suitable to secure the protection of rights.

\section{Conclusion}

The inclusion of socio-economic rights under the Constitution fulfils the legislative obligation imposed by the International Covenant of Economic Social and Cultural Rights and the Banjul Charter on Zimbabwe as a state party. Zimbabwe sought to set up a framework to ensure socio-economic rights in the Constitution are promoted and 
protected, where necessary proper redress is provided. This framework includes a proactive judiciary that is independent. This study demonstrated that judicial enforcement of socio-economic rights is paramount to the realisation and protection of these rights. It was shown that a proactive judiciary which is independent and impartial is a key institutional player in the domestic framework for protecting socio-economic rights. This is despite the fact that there are conceptual and practical challenges that arise in the enforcement of these rights, such as institutional competency of the courts, crafting appropriate judicial remedies for the violations of socio-economic rights, among others. Thus for effective enforcement of these rights under the Constitution, it was shown that courts must avoid pedantic and rigid interpretation of rights. Rather it was illustrated that a generous and purposive approach taking into account founding values, international human rights law norms and foreign law is beneficial towards the effective promotion and protection of socio-economic rights.

Additionally, this article demonstrated that courts must not solely depend on either reasonableness or minimum core approach but instead, courts must consider adopting an integrated approach that comprises both reasonableness approach and minimum core approach. Such an integrated approach will ensure that no one is deprived of the basic necessities of life at the same time allowing the government certain latitude to revise its laws and policies in line with the reasonable approach.

It was also illustrated in this article that crafting judicial remedies for violations of socio-economic rights is one of the practical challenges in the enforcement of these rights. This is because traditional remedies such as declaratory relief alone are not sufficient. Thus, this article demonstrated that structural injunctive relief with supervisory orders is more suited to curb the violations of socio-economic rights.

\section{List of References}

- Alfredson G, International Monitoring Mechanisms (2001) Martinus Nijhoff Publishers, Netherlands.

- Bilchitz D, "Giving Socio-Economic Rights Teeth: The Minimum Core and Its Importance" (2002) 118 South African Law Journal 484-501. 


\section{The Role of Courts in Enforcement of Socio-Economic Rights: 2013 Constitution of Zimbabwe 53}

- Bilchitz D, "Towards a Reasonable Approach to the Minimum Core: Laying the Foundations for Future Socio-economic Rights Jurisprudence" (2003) 19 South African Journal on Human Rights 1-26.

- Bilchitz D, Poverty and Fundamental Rights: The Justification and Enforcement of SocioEconomic Rights (2008) Oxford Press, London.

- Brundige E, \& Kalantry S, "Socio-Economic Rights: Adjudication under a Transformative Constitution (review)" (2012) 34 Human Rights Quarterly 579-601.

- Chowdhury J, "Judicial Adherence to a Minimum Core Approach to Socio-Economic Rights-A Comparative Perspective" (2009) 1 Cornell Law School Inter-University Graduate Student Conference Papers, Paper 27. Available at http://scholarship.law.cornell.edu/lps_clacp/27

- Christiansen E C, "Adjudicating non-justiciable rights: Socio-Economic Rights and the South African Constitutional Court" 38 Columbia Human Rights Law Review (2006-2007) 321-386.

- Committee on Economic, Social and Cultural Rights General Comment No 3 The Nature of States Parties' Obligations (1990) UN Doc E/1991/23.

- Craven M, "The Domestic Application of the International Covenant on Economic, Social and Cultural Rights" (1993) 40 Netherlands International Law Review 367-404.

- Craven M, The International Covenant on Economic, Social and Cultural Rights (1995) Oxford, University Press, London.

- Currie I \& de Waal J, The Bill of Rights Handbook (2013) Juta, Cape Town.

- Dankwa V, Flinterman C, Leckie S, Chapman A. R, Leary, V, \& Coomans F, "The Maastricht Guidelines on Violations of Economic, Social and Cultural Rights" (1998) 20 Human Rights Quarterly 691-694.

- de Bourbon A, "Human rights litigation in Zimbabwe, Past, Present and Future" (2003) 3 African Human Rights Law Journal 1-27.

- de Wet E, The Constitutional Enforceability of Economic and Social Rights (1996) Butterworths, Durban.

- Dumbutshena E, "Judicial Activism in the Quest for Justice and Equity" in Ajibola and Van Zyl (eds) The Judiciary in Africa (1998) Kenwyn, Juta. 
- Eide A, Economic, Social and Cultural Rights (2001) Martinus Nijhoff Publishers, Dordrecht/Boston/London.

- Heyns C and Stefiszyn K, Human Rights, Peace and Justice in Africa (2006) PULP Press, Pretoria.

- International Covenant on Economic, Social and Cultural Rights (1966) UN Doc A/6316.

- Kapindu R, "Courts and the Enforcement of Socio-economic Rights in Malawi, Jurisprudential Trends, Challenges and Opportunities" (2013) 13 African Human Rights Law Journal 1-27.

- Kende M.S, "The South African Constitutional Court's Construction of Socio - Economic Rights: A Response to Critics" (2003-2004) 19 Conn Journal International Law 617-630.

- Lennington G, Constitutional Law of Zimbabwe (2001) Legal Resources Foundation Publisher, Harare.

- Liebenberg "Forging New Tools for Vindicating the Rights of the Poor in the Crucible of the Eastern Cape" Public Lecture delivered at Rhodes University, Faculty of Law Faculty on 28 July 2014.

- Liebenberg S, "Reflections on Drafting a Bill of Rights: A South African Perspective" in N Kersting (ed) Constitution in Transition: Academic Inputs for a New Constitution in Zimbabwe (2009) GTZ and Friedrich Ebert Shiftung, Zimbabwe.

- Liebenberg S, "The Interpretation of Socio-Economic Rights" in M Chaskalson et al (ed) Constitutional Law of South Africa 2nd (ed) Original Service (2003) Juta, Cape Town.

- Liebenberg S, "The Value of Human Dignity in Interpreting Socio-Economic Rights" in AJ van der Walt (ed) Theories of Social and Economic Justice (2005) Sun Press Media: Stellenbosch 141-167.

- Liebenberg S, "Towards a Transformative Adjudication of Socio-economic Rights" (2007) 1 Speculum Juris 41-59.

- Liebenberg S, "Violations of Socio-Economic Rights: The Role of the South African Human Rights Commission" in P Andrews \& S Ellmann (eds) The Post-Apartheid Constitutions: Perspectives on South Africa's Basic law (2001) Witwatersrand University Press and Ohio University Press, Athens.

- Liebenberg S, Socio-Economic Rights: Adjudication under a Transformative Constitution (2010) Juta, Cape Town 


\section{The Role of Courts in Enforcement of Socio-Economic Rights: 2013 Constitution of Zimbabwe 55}

- Mbazira C, Litigating Socio-Economic Rights in South Africa: A Choice between Corrective and Distributive Justice (2009) PULP Press, Pretoria

- Nowak M, Introduction to Human Rights (2003) Martinus Nijhoff Publishers, Netherlands.

- Ntlama N, "Monitoring the Implementation of Socio-Economic Rights in South Africa: Some Lessons from the International Community (2009) 8 Law, Democracy and Development 207-220.

- Olowu D, An Integrative Right Based Approach to Human Development in Africa (2009) PULP Pretoria.

- Optional Protocol to the International Covenant on Economic, Social and Cultural Rights (2008) A/RES/63/117.

- Osode PC and Glover G (eds), Law and Transformative Justice in Post-Apartheid South Africa (2010) Spekboom Publishers, Louis Trichardt, South Africa.

- Pieterse M, "Coming to terms with Judicial Enforcement of Socio-Economic Rights" (2004) 20 South African Journal on Human Rights 383.

- Pieterse M, "Eating Socio-economic Rights: The Usefulness of Rights Talk in Alleviating Social Hardship Revisited" (2007) 29 Human Rights Quarterly 796-822.

- Pieterse M, "Possibilities and Pitfalls in the Domestic Enforcement of Social Rights: Contemplating the South African Experience" (2004) 26 Human Rights Quarterly 882-905.

- Rehman J, International Human Rights Law (2010) 2 ed Longman Print, London.

- Roach K, "The Challenges of Crafting Remedies for Violations of Social, Economic and Cultural Rights" in M. Langford (ed), Social Economic Rights Jurisprudence: Emerging Trends in International and Comparative Law (2009) Cambridge University Press 46-58.

- Roach K, and Bunlender G, "Mandatory Relief and Supervisory Jurisdiction: When is it Appropriate, Just and Equitable?" (2005) 122 South African Law Journal 325-351.

- Squires J, Langfold M and Thiele B (eds), The Road to a Remedy Current Issues in the Litigation of Economic, Social and Cultural Rights (2005) Australian Human Rights Centre Australia.

- Ssenyonjo M, Economic, Social Cultural Rights in International Law (2009) Hart Publishing, Oxford, Portland Oregon.

- Steiner H.J, Alston P and Goodman R, International Human Rights in Context (2007) 3 ed Oxford University Press London. 
- The Constitution of the Republic of South Africa 1996.

- The Constitution of the Republic of Zimbabwe 2013.

- The Lancaster House Constitution 1980

- Whelan D.J, Indivisible Human Rights a History (2010) University of Pennsylvania Press, USA.

- Zimbabwe Lawyers for Human Rights, Economic Social and Cultural Rights in Zimbabwe: Options for Constitutional Protection (2009), International Human Rights Clinic, Harvard Law School.

AUTHOR'S CONTACT:

NDHLOVU, $\mathbf{N}$.

Nelson R. Mandela School of Law Faculty of Law

University of Fort Hare

Email: 200909683@ufh.ac.za 